Menoufia J. Soil Sci.,Vol. 3 February (2018) : 17 - 36

\title{
EFFECT OF BIOCHAR AND COMPOST APPLICATIONS ON MACRONUTRIENTS LOSS FROM SANDY SOIL
}

\author{
R. A. Khalil, M. Abo El-Fadal, S. A. Radwan, E. A. Abou Hussien \\ and $\mathrm{H}$. Mahrous
}

Soil Sci. Dep., Fac. of Agric., Menoufia Univ. Shebin El-Kom, Egypt

Received: Nov. 5, 2017

Accepted: Dec. 10, 2017

\begin{abstract}
Columns experiment was conducted at the laboratory of Soil Sci. Dept., Fac. of Agric., Menoufia Univ., Shebin Elkom, Egypt to study impact of two organic amendments (biochar and compost derived from rice straw) application to sandy soil samples collected from

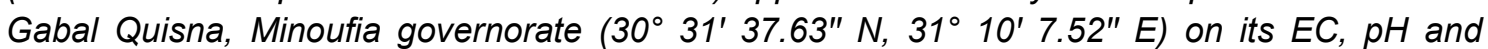
content of soluble $\mathrm{NH}_{4}, \mathrm{NO}_{3}, \mathrm{P}$ and $\mathrm{K}$. This study was carried out using columns of polyethylene and prior to packing the columns. The prepared soil samples were mixed and thoroughly homogenized with $0.00,0.75,1.50$ and $3.00 \%$ compost (RSC) and/or 0.00, 0.75, 1.50 and 3.00\% biochar (RSB). All soil columns were supplied by nutrient solution (Hewitt and smith, 1975), moistened to field capacity level and incubated at the room temperature for 25 days. At the end of incubation period, all soil columns were leached by water to $180 \%$ WHC of the studied soil for 3 times with a ten-day interval. The obtained results indicated that, increasing biochar rates led to an increase of $\mathrm{pH}, \mathrm{EC}$ and soluble content of $\mathrm{K}$ and a decrease of soluble $\mathrm{NH}_{4}{ }^{+}, \mathrm{NO}_{3}{ }^{-}$and $\mathrm{P}$ in the leachate. The compost applications conduced to an increase of EC, soluble $\mathrm{NH}_{4}{ }^{+}, \mathrm{NO}_{3}{ }^{-}, \mathrm{P}$ and $\mathrm{K}$ and a decrease of $\mathrm{pH}$ in the leachate.
\end{abstract}

Key words: Columns, Sandy soil, Compost, Biochar, EC, pH, Soluble macronutrients.

\section{INTRODUCTION}

Composting is the bioconversion and decomposition of organic biodegradable materials by heterotrophic and autotrophic microorganisms (bacteria, fungi, actinomycetes and protozoa) into humus-like material called compost (Epstein, 1997). It has become one of the most important waste technologies. This natural process provides the fight organisms, moisture, aerobic conditions, feed material and nutrients are available for microbial growth. By controlling these factors the composting process can occur at a much faster rate (Kumar et al., 2008). Biochar is the solid material produced during a process known as pyrolysis from the thermo-conversion of biomass under little or no oxygen for use as ameliorate to the soil (Gaskin et al., 2008 and Lehmann and Joseph 2009). During pyrolysis, labile carbon (C) is converted into a relatively stable aromatized C (Krull et al., 2009).
Angelova et al. (2013) found that, application of compost reduced the soil $\mathrm{pH}$ significantly as compared to control. In this respect Aiad (2010), Gohar (2011) and Elgezery (2016) obtained similar results. Ali, Laila (2001) demonstrated that, the $\mathrm{pH}$ values of cultivated sandy soil were slightly decreased after wheat and corn harvesting due to the application of cotton stalks or rice straw compost. Nigussie et al. (2012) indicated that, the addition of biochar to soils caused to increase of their $\mathrm{pH}$ values. Arthur et al. (2012) studied the effect of three compost types (vegetable, fruit and yard waste compost, garden waste compost, and spent mushroom compost) on basic properties of a loamy sand and greenhouse tomato productivity. They found that all compost types significantly increased soil electrical conductivity. Kookana et al. (2011) showed that, the application of biochar to soil resulted in an immediate increase in soil electrical conductivity (EC). 
Leaching is the common way for $\mathrm{N}$ loss from fertilizer, resulting in potential groundwater pollution (Goulding, 2000). The organic amendments significantly $(p \leq 0.05)$ increased some soil chemical parameters, including available $\mathrm{NO}_{3}-\mathrm{N}$ and $\mathrm{NH}_{4}{ }^{+}-\mathrm{N}$ (Agegnehu et al., 2016). Application of compost at high rates could result in leaching of some nutrients (i.e. $\mathrm{NH}_{4}-\mathrm{N}$ ) from the topsoil, and may lead to contamination of groundwater (Peverly and Gates, 1994). Increasing rates of added compost were associated with an increase of available $\mathrm{NO}_{3}-\mathrm{N}$ in the sandy soil. The increase of $\mathrm{NO}_{3}-\mathrm{N}$ content in the soil was followed by compost applications attributed to its high content of $\mathrm{N}$ and its effect on the increase of microbial activity in soil (Elgezery, 2016). Application of biochar can increase soil fertility and crop productivity by reducing the leaching of nutrients or even supplying nutrients to plants (Lehmann et al., 2003 and Major et al., 2010). Iqbal et al. (2015) found that, biochar amendments did not significantly reduce the leaching of dissolved organic carbon, nitrate, and phosphorus as compared to the compost treatments. Speir et al. (2004) reported that, the soil $P$ increased markedly with increasing compost application rate. Xu et al. (2014) found that, the biochar addition to alkaline soils associated with an increase of available P. Nigussie et al. (2012) found that, the amount of available phosphorous in soils were significantly $\quad(P<0.01) \quad$ increased by application of biochar. Elgezery (2016) found that, the calcareous sandy soil treated with compost have a high content of available $\mathrm{K}$ compared to the untreated soil. This content was increased with the increase rate of added compost. Also, Aaid (2010), Gohar (2011) and Abou Hussien et al. (2017) have obtained similar results in sandy soils treated with compost. Novak et al. (2012) concluded that, the $\mathrm{K}$ leached through the sands was more than that through the silt loam soil. Biochar drived from manure has significantly increased the leachate $\mathrm{K}$ from the soil. This studied revealed that, the concentration of water soluble $\mathrm{K}$ was highly variable and both sands were prone to $\mathrm{K}$ leaching losses.
The aim of this work is to study the impact of two organic amendments (RSC and RSB) applied to sandy soil on its $\mathrm{EC}, \mathrm{pH}$ and content of soluble $\mathrm{NH}_{4}{ }^{+}, \mathrm{NO}_{3}{ }^{-}, \mathrm{P}$ and $\mathrm{K}$.

\section{MATERIALS AND METHODS}

Surface $(0-30 \mathrm{~cm})$ sandy soil samples were collected from Gabal Quisna, Menoufia governorate $\left(30^{\circ} 31^{\prime} 37.63^{\prime \prime} \mathrm{N}, 31^{\circ} 10^{\prime} 7.52^{\prime \prime}\right.$ E). Soil samples were air-dried, homogeneously mixed and sieved through a $2 \mathrm{~mm}$ sieve and analyzed for some physical and chemical properties (Table 1) according to Cottenie et al. (1982), Page et al. (1982) and Klute and Dirksen (1986). Two types of amendments namely, compost and biochar were prepared from rice straw. The chemical analyses of these amendments were carried out according to the methods described by Page et al. (1982). The obtained data are presented in Table (2).

\section{Leaching Experiment}

This study was carried out using soil columns in the laboratory condition of Soil Sci. Dept., Fac. of Agric., Menoufia Univ., Shebin Elkom, Egypt to study the effect of individual and/or combined applications of rice straw compost (RSC) and biochar (RSB) on leachates of sandy soil $\mathrm{pH}, \mathrm{EC}$ and content of soluble $\mathrm{NH}_{4}{ }^{+}, \mathrm{NO}_{3}{ }^{-}, \mathrm{P}$ and $\mathrm{K}$. In this study, polyethylene columns having dimensions of $8.25 \mathrm{~cm}$ inner diameter and $25 \mathrm{~cm}$ height were used. The columns tops were kept open to prevent anaerobic conditions. Prior to packing the columns, a small layer of glass wool was placed in the bottom of each column to prevent soil and/or amendments leaching out. Another layer of coarse sand $(2 \mathrm{~cm})$ was placed over the glass wool layer. The prepared soil was mixed and thoroughly homogenized with RSC and /or RSB at different mixed ratios (oven dry weight equivalent) which represented the studied treatments in this experiment as listed in Table (3). Each plastic column was filled with $1.5 \mathrm{~kg}$ of soilRSC and /or RSB mixture. The studied treatments in this experiment were arranged randomly with three replicates. 


\begin{tabular}{|c|c|c|c|c|c|c|c|c|}
\hline 咅 & \multirow{4}{*}{ 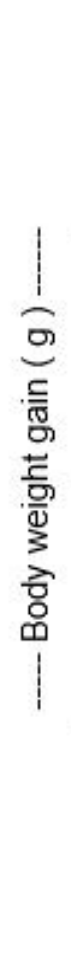 } & 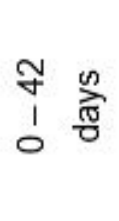 & 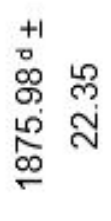 & 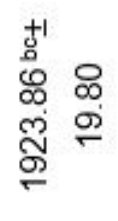 & $\begin{array}{l}+1 \\
0 \\
0 \\
\infty \\
\infty \\
\infty \\
\infty \\
\stackrel{\sigma}{\sigma} \\
\stackrel{\sigma}{\sigma}\end{array}$ & 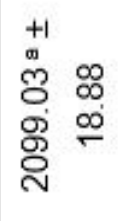 & 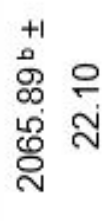 & \multirow{9}{*}{ 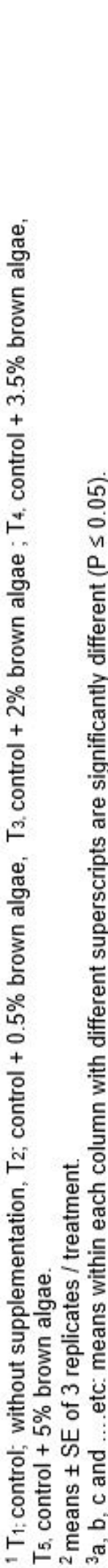 } \\
\hline 궁 & & 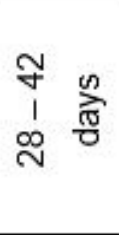 & 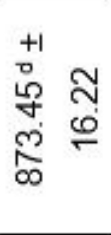 & $\begin{array}{l}+1 \\
0 \\
\stackrel{0}{0} \\
\frac{\omega}{\infty} \\
\stackrel{\infty}{\infty}\end{array}$ & 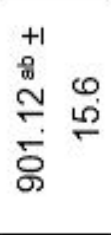 & 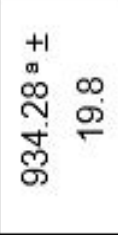 & 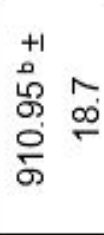 & \\
\hline$\frac{\mathbf{y}}{x}$ & & $\stackrel{\stackrel{\infty}{N}}{\underset{t}{t}} \underset{\frac{\pi}{0}}{\stackrel{n}{0}}$ & 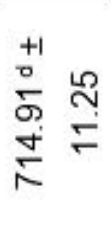 & 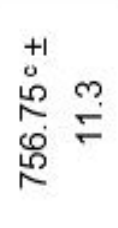 & $\begin{array}{l}+1 \\
0 \\
\infty \\
\stackrel{0}{0} \\
\stackrel{0}{0}\end{array}$ & 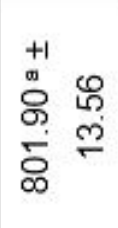 & 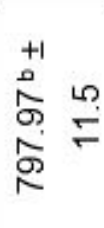 & \\
\hline 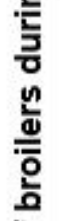 & & 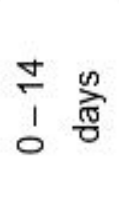 & $\begin{array}{ll}+1 & \\
0 & \\
\dot{+} & N \\
N & N \\
\text { N } & \end{array}$ & 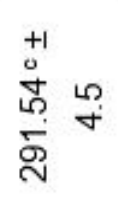 & $\begin{array}{l}+1 \\
\stackrel{+}{N} \sim \\
\stackrel{N}{n}\end{array}$ & 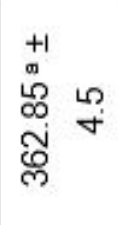 & 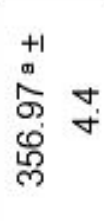 & \\
\hline 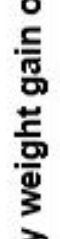 & \multirow{4}{*}{ 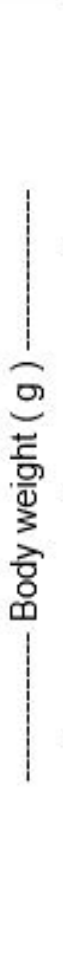 } & $\begin{array}{l}\text { ํํㅁ } \\
\stackrel{\text { y }}{y}\end{array}$ & 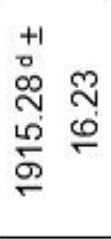 & 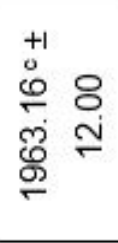 & 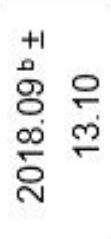 & 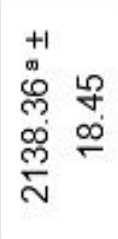 & $\begin{array}{l}+1 \\
\stackrel{+1}{\alpha} \\
\stackrel{2}{\circ} \\
\stackrel{\circ}{\circ}\end{array}$ & \\
\hline$\frac{8}{\frac{8}{2}}$ & & $\begin{array}{l}\text { त्ञ } \\
\text { D } \\
\text { ㅇ }\end{array}$ & 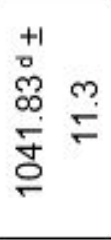 & 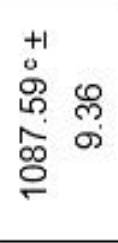 & 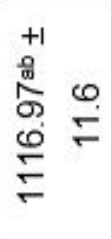 & 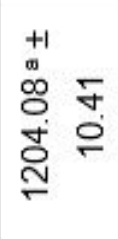 & \begin{tabular}{l}
+1 \\
$\stackrel{+1}{N}$ \\
\multirow{N}{*}{} \\
$\stackrel{0}{\circ}$ \\
$\stackrel{0}{\rightleftharpoons}$
\end{tabular} & \\
\hline 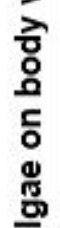 & & 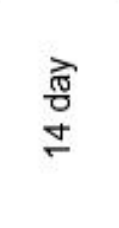 & 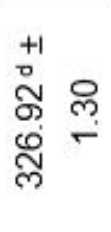 & 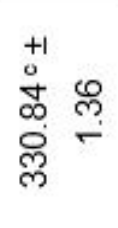 & 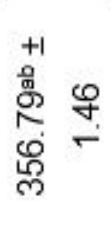 & 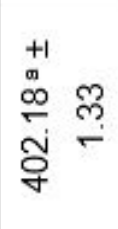 & 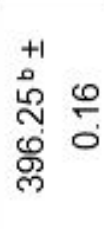 & \\
\hline 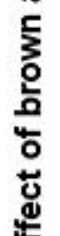 & & 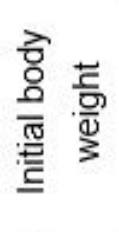 & 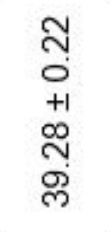 & 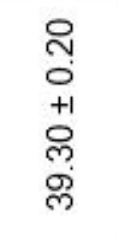 & 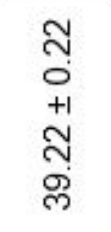 & $\begin{array}{l}\text { స̃ } \\
\text { o } \\
+1 \\
\text { లె } \\
\text { ळె }\end{array}$ & 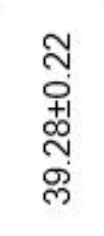 & \\
\hline$\frac{\dot{\frac{j}{0}}}{\frac{0}{\frac{0}{0}}}$ & & 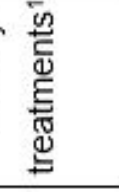 & 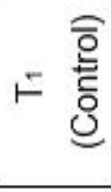 & $\stackrel{N}{F}$ & $\stackrel{m}{F}$ & $\vdash$ & $\stackrel{\text { ம }}{\circ}$ & \\
\hline
\end{tabular}


Table (3): Rank and application rates of RSC and RSB treatments used in the leaching experiment.

\begin{tabular}{|l|c|c|c|c|}
\hline \multirow{2}{*}{$\begin{array}{l}\text { RSC } \\
\text { treatments }\end{array}$} & \multicolumn{4}{|c|}{ RSB treatments } \\
\cline { 2 - 5 } & $\mathrm{B}_{0.00}(0.00 \%)$ & $\mathrm{B}_{0.75}(0.75 \%)$ & $\mathrm{B}_{1.50}(1.50 \%)$ & $\mathrm{B}_{3.00}(3.00 \%)$ \\
\hline $\mathrm{C}_{0.00}(0.00 \%)$ & $\mathrm{C}_{0.00} \mathrm{~B}_{0.00}$ & $\mathrm{C}_{0.00} \mathrm{~B}_{0.75}$ & $\mathrm{C}_{0.00} \mathrm{~B}_{1.50}$ & $\mathrm{C}_{0.00} \mathrm{~B}_{3.00}$ \\
\hline $\mathrm{C}_{0.75}(0.75 \%)$ & $\mathrm{C}_{0.75} \mathrm{~B}_{0.00}$ & $\mathrm{C}_{0.75} \mathrm{~B}_{0.75}$ & $\mathrm{C}_{0.75} \mathrm{~B}_{1.50}$ & $\mathrm{C}_{0.75} \mathrm{~B}_{3.00}$ \\
\hline $\mathrm{C}_{1.50}(1.50 \%)$ & $\mathrm{C}_{1.50} \mathrm{~B}_{0.00}$ & $\mathrm{C}_{1.50} \mathrm{~B}_{0.75}$ & $\mathrm{C}_{1.50} \mathrm{~B}_{1.50}$ & $\mathrm{C}_{1.50} \mathrm{~B}_{3.00}$ \\
\hline $\mathrm{C}_{3.00}(3.00 \%)$ & $\mathrm{C}_{3.00} \mathrm{~B}_{0.00}$ & $\mathrm{C}_{3.00} \mathrm{~B}_{0.75}$ & $\mathrm{C}_{3.00} \mathrm{~B}_{1.50}$ & $\mathrm{C}_{3.00} \mathrm{~B}_{3.00}$ \\
\hline
\end{tabular}

All soil columns were supplied by standard nutrient solution of (Hewitt and smith, 1975) and incubated at room temperature for 25 days at moisture level of field capacity. At the end of incubation period, all soil columns moistened by $180 \%$ WHC of the soil without treatments $\left(\mathrm{C}_{0} \mathrm{~B}_{0}\right)$ for 3 times with a ten-day interval. Water application was carried out from the columns tops through burettes mounted above the middle of each column. Filter paper was placed on the soil surface to dissipate the added water drops on the surface of soil column. The leachate of each column was collected during leaching periods, measured volumetrically and kept in clean and dried bottle. The collected leachate of each column was analyzed for its $\mathrm{pH}$, EC (1:10) the content of soluble $\mathrm{NO}_{3}{ }^{-}, \mathrm{NH}_{4}{ }^{+}, \mathrm{P}$ and $\mathrm{K}$ according to the methods described by Cottenie et al. (1982).

\section{RESULTS AND DISCUSSION Effect of Biochar and/or Compost on Leachates Chemical Composition \\ 1. Leachate $\mathrm{pH}$}

Data in Table (4) illustrate the combined effect of incubation periods, sources and rates of organic amendments addition on the $\mathrm{pH}$ values of leachates. Data showed clearly that, there was an obvious difference in $\mathrm{pH}$ values as a result of impact of the studied factors. Generally results revealed that, the highest $\mathrm{pH}$ value (9.2) was obtained at the first period (at 25 days from the beginning of the incubation) and with $\mathrm{C}_{0} \mathrm{~B}_{3}$ treatment. On the other hand, the lowest one (6.8) was obtained at the third incubation period with no addition of compost and biochar $\left(\mathrm{C}_{0} \mathrm{~B}_{0}\right)$. Regarding to the effect of incubation periods on $\mathrm{pH}$, it was found that, the highest $\mathrm{pH}$ values were $9.2\left(\mathrm{C}_{0} \mathrm{~B}_{3}\right), 8.5\left(\mathrm{C}_{0} \mathrm{~B}_{3}\right)$ and 8.7 $\left(\mathrm{C}_{3} \mathrm{~B}_{3}\right)$ at $1^{\text {st }}, 2^{\text {nd }}$ and $3^{\text {rd }}$, incubation period respectively. On the other hand, the lowest $\mathrm{pH}$ leachate values were $7.0\left(\mathrm{C}_{3} \mathrm{~B}_{0}\right), 6.90$ $\left(\mathrm{C}_{0} \mathrm{~B}_{0}\right)$ and $6.80 \quad\left(\mathrm{C}_{0} \mathrm{~B}_{0}\right)$ at the above mentioned incubation periods respectively. It can be concluded that, the addition of biochar led to an increase in $\mathrm{pH}$ values of leachate. While the opposite trend was noticed with the application of compost at the first leaching. These findings could be attributed to continuous and rapid changes occurred in compost composition during incubation period and also to type and chemical composition of organic and inorganic products resulted from compost decomposition.

Generally, the presented data in Table (4) show that, the combined applications of compost and biochar were associated with an increase of leachate $\mathrm{pH}$ in the three periods comparing with control or the individual treatments of compost. The obtained $\mathrm{pH}$ values were affected by the used organic amendments, its application rates and leaching number. The changes of leachates $\mathrm{pH}$ values under the combined treatments of biochar and compost in the three leachings periods may be cleared from the relative change "RC" values (\%) of the obtained $\mathrm{pH}$. These values were positive with all combined treatments compared with the control treatment (Table, 4). 
Table (4): Values of sandy soil Leachates pH and its relative change "RC" (\%) as affected by different applications of biochar (RSB) and/or compost (RSC) at three incubation periods.

\begin{tabular}{|c|c|c|c|c|c|c|c|}
\hline \multirow{2}{*}{\multicolumn{2}{|c|}{$\begin{array}{c}\text { Organic } \\
\text { amendments }\end{array}$}} & \multicolumn{6}{|c|}{ Incubation periods } \\
\hline & & \multicolumn{2}{|c|}{$1^{\text {st }}$} & \multicolumn{2}{|c|}{$2^{\text {nd }}$} & \multicolumn{2}{|c|}{$3^{\text {th }}$} \\
\hline RSC\% & RSB\% & $\mathrm{pH}$ values & $\mathrm{RC} \%$ & $\begin{array}{c}\mathrm{pH} \\
\text { values }\end{array}$ & RC\% & $\mathrm{pH}$ values & $\mathrm{RC} \%$ \\
\hline \multirow{6}{*}{0.00} & 0.00 & 7.30 & 0.00 & 6.90 & 0.00 & 6.80 & 0.00 \\
\hline & 0.75 & 7.60 & 4.11 & 7.20 & 4.35 & 7.20 & 5.88 \\
\hline & 1.50 & 7.90 & 8.22 & 7.80 & 13.04 & 7.70 & 13.24 \\
\hline & 3.00 & 9.20 & 26.03 & 8.50 & 23.19 & 8.30 & 22.06 \\
\hline & Mean & 7.98 & 9.32 & 7.60 & 10.14 & 7.50 & 10.29 \\
\hline & 0.00 & 7.20 & -1.37 & 7.50 & 8.70 & 7.00 & 2.94 \\
\hline \multirow{4}{*}{0.75} & 0.75 & 7.30 & 0.00 & 7.60 & 10.14 & 7.30 & 7.35 \\
\hline & 1.50 & 7.60 & 4.11 & 7.80 & 13.04 & 7.80 & 14.71 \\
\hline & 3.00 & 8.10 & 10.96 & 8.10 & 17.39 & 8.10 & 19.12 \\
\hline & Mean & 7.53 & 3.15 & 7.75 & 12.32 & 7.40 & 8.82 \\
\hline \multirow{9}{*}{1.50} & 0.00 & 7.10 & -2.74 & 7.20 & 4.35 & 7.10 & 4.41 \\
\hline & 0.75 & 7.40 & 1.37 & 7.50 & 8.70 & 7.50 & 10.29 \\
\hline & 1.50 & 7.50 & 2.74 & 7.90 & 14.49 & 7.70 & 13.24 \\
\hline & 3.00 & 7.70 & 5.48 & 8.30 & 20.29 & 8.20 & 20.59 \\
\hline & Mean & 7.45 & 2.05 & 7.73 & 12.03 & 7.63 & 12.21 \\
\hline & 0.00 & 7.00 & -4.11 & 7.50 & 8.70 & 7.20 & 5.88 \\
\hline & 0.75 & 7.20 & -1.37 & 7.70 & 11.59 & 7.40 & 8.82 \\
\hline & 1.50 & 7.30 & 0.00 & 8.20 & 18.84 & 7.50 & 10.29 \\
\hline & 3.00 & 7.40 & 1.37 & 8.40 & 21.74 & 8.70 & 27.94 \\
\hline 3.00 & Mean & 7.23 & -0.96 & 7.95 & 15.22 & 7.65 & 12.50 \\
\hline
\end{tabular}

Data in Table (4) presented the leachate $\mathrm{pH}$ values and their relative changes (RC \%) after three incubation periods $(25,35$ and 45 days) affected by the individual applications of compost or biochar added to sandy soil samples. These data showed that, values of $\mathrm{pH}$ increased with the increase rates of added biochar alone at the three periods compared with the control treatment. This effect was in contract with the individual treatments of compost at the first leaching (at 25 days). Similar finding was reported by Angelova et al. (2013) who found that, application of compost reduced the soil $\mathrm{pH}$ significantly as compared to control. Also, Kookana et al. (2011) who stated that, the 
application of biochar to soil resulted in an immediate increase in $\mathrm{pH}$. The increase in soil $\mathrm{pH}$ with the application of biochar could be generally attributed to its ash accretion which is generally dominated by carbonates and alkaline earth metals and its few amounts of organic and inorganic $\mathrm{N}$ (Nigussie et al., 2012). In other study on application of compost to soil, Gohar (2011) and Elgezery (2016) obtained similar results.

Relative changes "RC" (\%) of leachates $\mathrm{pH}$ affected by the individual treatmants of biochar and compost were calculated and obtained values were recorded in Table (4). These values were positive for the three leachings of samples treated with biochar and were negative in the leachate of samples treated only by compost for the first leaching only.

The effect of addition rates (R) of individual biochar or compost on $\mathrm{pH}$ values of the leachate from sandy soil samples can be expressed as the following equations:

Biochar $\mathrm{H}=0.563 \mathrm{R}_{\mathrm{a}}+6.96 \quad\left(\mathrm{R}^{2}=0.99\right)$ Compost $\mathrm{pH}=0.058 \mathrm{R}_{\mathrm{a}}+7.073\left(\mathrm{R}^{2}=0.99\right)$ Where, $\mathrm{R}_{\mathrm{a}}$ is application rate $\%$

These equations revealed that, $\mathrm{pH}$ values of leachate as affected with application rates $(R)$ were higher by addition of biochar than compost. The previous equations showed that, the increasing rate of $\mathrm{pH}$ in the case of adding biochar was higher than compost by 9.64 .

On the other hand, leachates of samples treated with biochar alone recorded high $\mathrm{pH}$ values in the first leaching. These values were slightly decreased in the second and third leachings (in most individual treatments of biochar). This trend could be attributed to remove the basic cations by water leaching. These findings were in harmony with biochar chemical composition especially its high stable structure. Similar results were obtained by Novak et al. (2009) and Granatstein et al. (2009) who stated that, chars made from herbaceous feedstocks (switchgrass, digester fiber, peanut hulls) had lower carbon contents, higher nitrogen contents, and higher $\mathrm{pH}$ than chars made from woody feedstocks . The data in Table (4) also showed that, at the same rate of added compost alone, leachates $\mathrm{pH}$ have a wide range among the three leachings compared with that found with biochar applications. These results reflect the high stable structure of biochar compared with compost and also to high decomposition rate occurred for compost by soil microorganisms compared with biochar as reported by Fischer and Glaser (2012).

It can be expressed with the following equations for the effect of incubation periods (days) on the $\mathrm{pH}$ values of leachates from sandy soil treated with different rates of compost and biochar.

In the case of biochar:

$\mathrm{pH}=-0.022 \mathrm{P}+8.47$

In the case of compost:

$\mathrm{pH}=-0.016 \mathrm{P}+7.64$

Where, $\mathrm{P}$ is incubation period (day)

These equations indicated that, the $\mathrm{pH}$ values of leachate generally, decreased with increasing incubation periods $(P)$ for the individual addition of compost and biochar. The decrease in $\mathrm{pH}$ values of leachate be more pronounced in the case of biochar than in compost as shown in Table (4). The previous equations cleared that, in the case of biochar, the rate of decline in $\mathrm{pH}$ values of leachate equal to 0.022 / day, while in the case of compost equal to $0.016 /$ day. These equations also illustrated that, the rate of decrease in $\mathrm{pH}$ values of leachate greater by 1.375 in the case of biochar than that, in the case of compost.

\section{Leachate EC (dSm-1)}

Data in Table (5) presented that, the individual and combined effect of both compost and biochar on leachate EC $\left(\mathrm{dSm}^{-1}\right)$ of soil samples through three incubation periods (25, 35 and 45 days). In general it can be observed that, the increase of incubation periods resulted in a decrease in EC $\left(\mathrm{dSm}^{-1}\right)$ values with the addition of 
compost or biochar. On the other hand, the increasing in application rates of both compost and/or biochar led to an increase in $\mathrm{EC}$ values. The highest value of leachate EC resulted from the combination between compost and biochar was $3.60 \mathrm{dSm}^{-1}$ with treatment of $\mathrm{C}_{3} \mathrm{~B}_{3}$ in the first period. The lowest value of EC was $0.20 \mathrm{dSm}^{-1}$ was recorded with control treatment $\left(\mathrm{C}_{0} \mathrm{~B}_{0}\right)$ in the $3^{\text {rd }}$ period.

The highest value of EC presented in Table (5) were 3.60, 2.9 and $1.8 \mathrm{dSm}^{-1}$ for the treatment of $\mathrm{C}_{3} \mathrm{~B}_{3}$ at first, second and third periods of incubations, respectively. The lowest values were $0.6,0.4$ and 0.2 $\mathrm{dSm}^{-1}$ for the treatment of $\mathrm{C}_{0} \mathrm{~B}_{0}, \mathrm{C}_{0.75} \mathrm{~B}_{0}$, respectively at the progressive periods.

Table (5): EC (dSm-1) values of sandy soil Leachates and its relative change "RC" (\%) as affected by different application rates of biochar (RSB) and/or compost (RSC) at three incubation periods.

\begin{tabular}{|c|c|c|c|c|c|c|c|}
\hline \multirow{2}{*}{\multicolumn{2}{|c|}{$\begin{array}{c}\text { Organic } \\
\text { amendments }\end{array}$}} & \multicolumn{6}{|c|}{ Incubation periods } \\
\hline & & \multicolumn{2}{|c|}{$1 \mathrm{st}$} & \multicolumn{2}{|c|}{ 2nd } & \multicolumn{2}{|c|}{ 3th } \\
\hline RSC\% & RSB\% & $\mathrm{EC}(\mathrm{dS} / \mathrm{m})$ & $\mathrm{RC} \%$ & $\mathrm{EC}(\mathrm{dS} / \mathrm{m})$ & $\mathrm{RC} \%$ & $\mathrm{EC}(\mathrm{dS} / \mathrm{m})$ & $\mathrm{RC} \%$ \\
\hline \multirow{4}{*}{0.00} & 0.00 & 0.60 & 0.00 & 0.45 & 0.00 & 0.20 & 0.00 \\
\hline & 0.75 & 0.80 & 33.33 & 0.60 & 33.33 & 0.30 & 50.00 \\
\hline & 1.50 & 1.15 & 91.67 & 0.80 & 77.78 & 0.40 & 100.00 \\
\hline & 3.00 & 1.60 & 166.67 & 0.96 & 113.33 & 0.56 & 100.00 \\
\hline & Mean & 1.04 & 72.92 & 0.70 & 56.11 & 0.33 & 62.50 \\
\hline \multirow{4}{*}{0.75} & 0.00 & 0.75 & 25.00 & 0.40 & -11.11 & 0.25 & 25.00 \\
\hline & 0.75 & 1.18 & 96.67 & 0.70 & 55.56 & 0.40 & 100.00 \\
\hline & 1.50 & 1.40 & 133.33 & 0.90 & 100.00 & 0.50 & 150.00 \\
\hline & 3.00 & 2.40 & 300.00 & 1.10 & 144.44 & 0.60 & 200.00 \\
\hline & Mean & 1.43 & 138.75 & 0.78 & 72.22 & 0.44 & 118.75 \\
\hline \multirow{4}{*}{1.50} & 0.00 & 1.10 & 83.33 & 0.65 & 44.44 & 0.40 & 100.00 \\
\hline & 0.75 & 1.40 & 133.33 & 1.00 & 122.22 & 0.50 & 150.00 \\
\hline & 1.50 & 1.85 & 208.33 & 1.40 & 211.11 & 0.70 & 250.00 \\
\hline & 3.00 & 2.90 & 383.33 & 1.50 & 233.33 & 0.75 & 275.00 \\
\hline & Mean & 1.81 & 202.08 & 1.14 & 152.78 & 0.59 & 193.75 \\
\hline \multirow{4}{*}{3.00} & 0.00 & 1.30 & 116.67 & 0.98 & 117.78 & 0.70 & 250.00 \\
\hline & 0.75 & 1.65 & 175.00 & 1.50 & 233.33 & 0.90 & 350.00 \\
\hline & 1.50 & 2.25 & 275.00 & 1.70 & 277.78 & 0.90 & 350.00 \\
\hline & 3.00 & 3.60 & 500.00 & 2.90 & 544.44 & 1.80 & 800.00 \\
\hline & Mean & 2.20 & 266.67 & 1.77 & 293.33 & 1.08 & 437.50 \\
\hline
\end{tabular}


This increasing effect was found with compost and biochar added individual or in combined application at different application rates. Data in Table (5) indicate that, EC $(\mathrm{dS} / \mathrm{m})$ values of leachates at the three leaching resulted from the combined treatments of compost and biochar were higher than these resulted from the individual application of compost or biochar. The rates of the EC increases as a result of the applied biochar and/or compost at the three leaching varied widely from treatment to another. These rates may be cleared from the calculated RC (\%) values of EC recorded in Table (5). In this respect Agegnehu et al. (2015) obtained similar results. Electrical conductivity (EC) in leachates of soil amended with compost and biochar together at three leachings were increased with the increase of added compost and biochar and more increase of EC was associated the increase of added biochar. Also, with all combined treatments of compost and biochar, EC values of first leaching were higher than those found in the leachates of both second and third leachings.

Data in Table (5) showed that, at the same rate of added compost and biochar, $E C$ values of leachates of the soil treated with biochar were slightly higher than those resulted from compost treatments. This increase may be due to biochar applications have a high solublizing effect on soil salts as result to high specific surface area of biochar and its high increase effect of soil porosity, water holding capacity and cation exchange capacity. Similar finding were obtained by Kookana et al. (2011), Lehmann et al. (2003) and Fowles (2007).

The effect of application rates $\left(R_{a}\right)$ of both compost and biochar on EC of leachate can be expressed with the following equation:

Compost: $E C=0.381+0.203 R_{a} \quad\left(R^{2}=0.97\right)$

Biochar: $E C=0.425+0.210 R_{a} \quad\left(R^{2}=0.99\right)$

Where $\mathrm{R}_{\mathrm{a}}=$ addition rate $\%$
These equations revealed that, the effect of application rates in the case of biochar was higher than that in compost. The increasing rate of EC value with increase $1 \%$ compost was $0.203 \mathrm{dS} / \mathrm{m}$, while in the case of biochar was $0.210 \mathrm{dS} / \mathrm{m}$. Meanwhile, the effect of application rates on EC values in the case of biochar was higher than that in the case of compost by1.03 times.

In addition, the data in Table (5) reveal that, with all treatments, leachates EC $(\mathrm{dS} / \mathrm{m})$ were decreased with the increase of leaching periods regardless of sources and rates. Generally, the Mean of EC values were $0.99,0.66$ and $0.38 \mathrm{dSm}^{-1}$ at the $1^{\text {st }}$, $2^{\text {nd }}$ and $3^{\text {rd }}$ period of incubation, respectively.

The impact of incubation time (days) on leachate EC can be expressed with the following equations:

Biochar: $\quad E C=1.878-0.0336 P \quad\left(R^{2}=1.00\right)$

Compos: $\quad E C=1.611-0.0275 P\left(R^{2}=0.99\right)$

Where $P$ =incubation period (days).

These equations pointed out that, the rates of EC decreasing were slightly higher in the case of biochar than in compost. These results may be taken as a clear indicator for the leachings effect on the decrease of soil salinity by removal soluble salts from the sandy soil treated by compost and biochar. Also, these data indicate the importance of leaching after soil organic amendments application especially under saline soil condition.

\section{Leachates content of soluble macronutrients \\ a. Soluble ammonium $\left(\mathrm{NH}_{4}-\mathrm{N}\right)$ content}

Loss of $\mathrm{NH}_{4}{ }^{+}$through leaching is a common way for $\mathrm{N}$ to be lost from fertilizer, resulting in potential groundwater pollution (Goulding, 2000).

Data in Table (6) show that, the leachates content of $\mathrm{NH}_{4}-\mathrm{N}$ widely varied according to leaching period and the studied treatments of compost and biochar. The same data demonstrated that, the highest 
content of soluble $\mathrm{NH}_{4}{ }^{+}$in sandy soil leachate was $5.4 \mathrm{meq} / \mathrm{L}$ with the treatment of $\mathrm{C}_{3} \mathrm{~B}_{0}$ at first period of incubation. The lowest content of soluble $\mathrm{NH}_{4}{ }^{+}$was 0.0 meq $\mathrm{NH}_{4}{ }^{+} / \mathrm{L}$ with the treatment of $\mathrm{C}_{0} \mathrm{~B}_{1.5}, \mathrm{C}_{0} \mathrm{~B}_{3}$, $\mathrm{C}_{0.75} \mathrm{~B}_{3}$ and $\mathrm{C}_{1.5} \mathrm{~B}_{3}$ at third incubation period. The highest values of $\mathrm{NH}_{4}{ }^{+}$(meq/L) in leachate were $5.4\left(\mathrm{C}_{3} \mathrm{~B}_{0}\right), 4.9\left(\mathrm{C}_{3} \mathrm{~B}_{0}\right)$ and 0.7 $\left(\mathrm{C}_{3} \mathrm{~B}_{0}\right)$ at first, second and third periods of incubation, respectively. While, the lowest contentof $\mathrm{NH}_{4}{ }^{+}$(meq/L) were $1.4\left(\mathrm{C}_{0} \mathrm{~B}_{3}\right)$, $0.20\left(\mathrm{C}_{0} \mathrm{~B}_{3}\right)$ and $0.00\left(\mathrm{C}_{0} \mathrm{~B}_{3}\right)$ at the $1^{\text {st }}, 2^{\text {nd }}$ and $3^{\text {rd }}$ periods of incubation, respectively. These results revealed that, soluble $\mathrm{NH}_{4}^{+}$ $(\mathrm{meq} / \mathrm{L})$ in the studied soil leachate was increased with increasing added rates of compost at the three incubation periods.

Table (6): Soluble $\mathrm{NH}_{4}-\mathrm{N}$ content (meq/L) in Leachate and its relative change "RC" (\%) as affected by different applications of biochar "RSB" and compost "RSC" at three incubation periods.

\begin{tabular}{|c|c|c|c|c|c|c|c|}
\hline \multirow{2}{*}{\multicolumn{2}{|c|}{$\begin{array}{c}\text { Organic } \\
\text { amendments }\end{array}$}} & \multicolumn{6}{|c|}{ incubations periods } \\
\hline & & \multicolumn{2}{|c|}{$1^{\text {st }}$} & \multicolumn{2}{|c|}{$2^{\text {nd }}$} & \multicolumn{2}{|c|}{$3^{\text {th }}$} \\
\hline $\mathrm{RSC} \%$ & RSB $\%$ & $\begin{array}{c}\mathrm{NH}_{4} \\
\mathrm{meq} / \mathrm{L}\end{array}$ & $\mathrm{RC} \%$ & $\begin{array}{c}\mathrm{NH}_{4} \\
\mathrm{meq} / \mathrm{L}\end{array}$ & $\mathrm{RC} \%$ & $\begin{array}{c}\mathrm{NH}_{4} \\
\mathrm{meq} / \mathrm{L}\end{array}$ & $\mathrm{RC} \%$ \\
\hline \multirow{5}{*}{0.00} & 0.00 & 3.10 & 0.00 & 2.50 & 0.00 & 0.40 & 0.00 \\
\hline & 0.75 & 2.60 & -16.13 & 1.50 & -40.00 & 0.10 & -75.00 \\
\hline & 1.50 & 1.90 & -38.71 & 1.40 & -44.00 & 0.00 & -100.00 \\
\hline & 3.00 & 1.40 & -54.84 & 0.20 & -92.00 & 0.00 & -100.00 \\
\hline & Mean & 2.25 & -27.42 & 1.40 & -44.00 & 0.13 & -68.75 \\
\hline \multirow{4}{*}{0.75} & 0.00 & 3.80 & 22.58 & 3.20 & 28.00 & 0.40 & 0.00 \\
\hline & 0.75 & 3.50 & 12.90 & 1.10 & -56.00 & 0.20 & -50.00 \\
\hline & 1.50 & 2.20 & -29.03 & 0.30 & -88.00 & 0.10 & -75.00 \\
\hline & 3.00 & 2.00 & -35.48 & 0.30 & -88.00 & 0.00 & -100.00 \\
\hline & Mean & 2.88 & -7.26 & 1.23 & -51.00 & 0.18 & -56.25 \\
\hline \multirow{4}{*}{1.50} & 0.00 & 4.20 & 35.48 & 4.30 & 72.00 & 0.40 & 0.00 \\
\hline & 0.75 & 3.90 & 25.81 & 2.80 & 12.00 & 0.10 & -75.00 \\
\hline & 1.50 & 3.30 & 6.45 & 1.70 & -32.00 & 0.10 & -75.00 \\
\hline & 3.00 & 2.90 & -6.45 & 0.90 & -64.00 & 0.00 & -100.00 \\
\hline & Mean & 3.58 & 15.32 & 2.43 & -3.00 & 0.15 & -62.50 \\
\hline \multirow{5}{*}{3.00} & 0.00 & 5.40 & 74.19 & 4.90 & 96.00 & 0.70 & 75.00 \\
\hline & 0.75 & 4.70 & 51.61 & 4.60 & 84.00 & 0.30 & -25.00 \\
\hline & 1.50 & 3.80 & 22.58 & 3.00 & 20.00 & 0.50 & 25.00 \\
\hline & 3.00 & 2.50 & -19.35 & 1.50 & -40.00 & 0.40 & 0.00 \\
\hline & Mean & 4.10 & 32.26 & 3.50 & 40.00 & 0.48 & 18.75 \\
\hline
\end{tabular}


On the contrary the soluble $\mathrm{HN}_{4}{ }^{+}$(meq/L) produced in leachate of sandy soil was decreased with increasing biochar rates. These results illustrated that, compost was ammonium producer but biochar was ammonium absorbent. Glaser et al. (2002), Lehmann et al., (2003) and Major et al. (2010) indicated that, the application of biochar can be reduced the leaching amounts of nutrient.

Increasing of biochar rate with particular compost rate in combined treatments led to a decrease in leachates contents of soluble $\mathrm{NH}_{4}-\mathrm{N}$ compared with the same rate of the compost alone. These contents were lower than that resulted from the individual compost applications and higher than that resulted from the individual applications of biochar. So, RC (\%) values of leachates contents of the soluble $\mathrm{NH} 4-\mathrm{N}$ affected by the combined treatments decreased with increasing biochar rates in the combined treatments at the same rate of compost. This trend was found in the three leaching.

Table (6) show that, in the same leaching period, the increasing rates of added biochar individually associated by a decrease of leachates content of $\mathrm{NH}_{4}-\mathrm{N}$ compared with control treatment. Ding et al. (2010) concluded that, bamboo biochar may be a potential amendment in soils for nutrient retention due to its adsorption properties and can theoretically retard nitrogenleaching losses. However, little information is available about the effect of biochar on inorganic nitrogen adsorption and cation exchange capacity in agricultural soil under leaching conditions. Therefore, the influence of biochar on nitrogen retention and leaching to groundwater during application of chemical fertilizers in soils needs to be further studied. Glaser et al. (2002), Lehmann et al. (2003) and Major et al. (2010) stated that, Application of biochar can increase soil fertility and crop productivity by reducing the leaching of nutrients or even supplying nutrients to plants. Regarding to the individual applications of compost, data indicated that, increasing compost rates associated by an increase of the content of soluble $\mathrm{NH}_{4}-\mathrm{N}$ $(\mathrm{meq} / \mathrm{L})$ in the sandy soil leachates. So, RC (\%) values of leachates content of $\mathrm{NH}_{4}-\mathrm{N}$ were positive with all individual application of compost. Such results were observed by Peverly and Gates (1994) who stated that, application of compost at high rates could result in leaching of some nutrients (i.e. $\mathrm{NH}_{4}$ $\mathrm{N})$ from the topsoil, and may lead to contamination of groundwater. The wide changes in the found of $\mathrm{NH}_{4}-\mathrm{N}$ (meq/L) may be defined and cleared from the calculated "RC" (\%) values of this content as shown in Table (6). These values were negative with individual applications of biochar and positive with the individual treatments of compost. The highest negative values of "RC" for leachates content of $\mathrm{NH}_{4}-\mathrm{N}$ were found in leachates of the samples treated by $3.00 \%$ biochar alone, but the highest positive RC values of this content were found in the leachates of the samples treated by $3.00 \%$ compost only. This trend was found in the three leaching.

The impact of each compost or biochar addition rates $\left(R_{a}\right)$ on the amounts of soluble ammonium in sandy soil leachate can be expressed by the following equation:

Compost: $\mathrm{HN}_{4}{ }^{+}(\mathrm{meq} / \mathrm{L})=2.05+0.555 \mathrm{Ra}$ $\left(\mathrm{R}^{2}=0.992\right)$

Biochar: $\mathrm{HN}_{4}{ }^{+}(\mathrm{meq} / \mathrm{L})=1.87-0.469 \mathrm{Ra}$ $\left(\mathrm{R}^{2}=0.964\right)$

Where $\mathrm{R}_{\mathrm{a}}=$ the addition rates $\%$

This equation indicated that, soluble ammonium in sandy soil leachate was increased by $0.555 \mathrm{meq} / \mathrm{L}$ with increasing compost rate by $1 \%$, while the amount of soluble ammonium in leachate was decrease as $0.469 \mathrm{meq} / \mathrm{L}$ when biochar was increased by $1 \%$.

These findings mean that, biochar has a high sorption capacity of $\mathrm{NH}_{4}-\mathrm{N}$ compared with that found with compost. Also may be suggested that, biochar applications to sandy soil prevent $\mathrm{NH}_{4}-\mathrm{N}$ leaching from soil 
and increased soil fertility compared with compost applications. These results are in agreement with those obtained by Lehmann (2007a) and Zhao et al. (2016).

Data in Table (6) show that, the highest contents were found in leachates of the first leaching and the lowest contents were found in the leachates of the third leaching with all treatments of biochar or/and compos. The effect of incubation periods $(25,35$ and 45 days) on vontent of soluble $\mathrm{NH}_{4}^{+}$(meq/L) in leachates can expressed with the following equations when compost or biochar was added to sandy soil.

Compost: $\quad \mathrm{NH}_{4}{ }^{+}(\mathrm{meq} / \mathrm{L})=9.16-0.182$ $\mathrm{Pi}\left(\mathrm{R}^{2}=0.992\right)$

Biochar: $\quad \mathrm{NH}_{4}{ }^{+}(\mathrm{meq} / \mathrm{L})=4.98-0.106 \mathrm{Pi}$ $\left(\mathrm{R}^{2}=0.964\right)$

Where $\mathrm{Pi}=$ incubation periods (days)

These equations revealed that, there was an inverse relationship between the soluble $\mathrm{HN}_{4}{ }^{+}$(meq/L) in the studied soil leachates and incubation periods when compost or biochar was added to sandy soil. On the other hand, the previous equations illustrated that, the decreasing in $\mathrm{HN}_{4}{ }^{+}$ (meq/L) in leachate was $0.182 \mathrm{meq} / \mathrm{L} / \mathrm{day}$ when compost was added to sandy soil. While the decreasing was $0.105 \mathrm{meq} / \mathrm{L} / \mathrm{day}$ when biochar was added to sandy soil.

\section{b. Soluble nitrate $\left(\mathrm{NO}_{3}-\mathrm{N}\right)$ content}

The combined effect of compost and biochar added together on soluble $\mathrm{NO}_{3}{ }^{-}$ (meq/L) of sandy soil leachates at three incubation periods (25, 35 and 45 days) illustrated that, applications of combined treatments (RSC+RSB) associated by an increase of sandy soil leachates content of $\mathrm{NO}_{3}-\mathrm{N}$ (meq/l) compared with control treatment. These increases were lower than that resulted from added compost alone and were higher than that resulted from added biochar alone. Increasing of biochar level with particular compost level in combined treatments led to slight decreases of leachates contents of soluble $\mathrm{NO}_{3}-\mathrm{N}$ compared with the same rate of the compost alone. These contents were lower than that resulted from the individual compost applications and higher than that resulted from the individual applications of biochar.

Data in Table (7) revealed that, the highest content of soluble $\mathrm{NO}_{3}^{-}(\mathrm{meq} / \mathrm{L})$ in leachates was $29.10 \mathrm{meq} / \mathrm{L}$ when sandy soil was treated with $\mathrm{C}_{3} \mathrm{~B}_{0}$ after 25 days of incubation. While the lowest $\mathrm{NO}_{3}-(\mathrm{meq} / \mathrm{L})$ value was $5.8 \mathrm{meq} / \mathrm{L}$ when sandy soil was treated with $\mathrm{C}_{0.75} \mathrm{~B}_{3}$ after 45 days of incubation. These findings may be become more clearly from the calculated RC (\%) values of NO3-N content in the leachates of samples soil treated by biochar and compost together. The highest $\mathrm{RC}(\%)$ values of $\mathrm{NO}_{3-}$ $\mathrm{N}$ content were found in the leachates of soil samples treated by low biochar rates and high compost rates (Table, 7). These findings were almost found in the leachates of the three leachings. Marofi et al. (2015) found that, waste water and compost could increase all leached nutrients comparing to the control.

Table (7) represented the individual effect of compost and biochar rates on soluble $\mathrm{NO}_{3}-(\mathrm{meq} / \mathrm{L})$ of sandy soil leachate at three incubation periods $(25,35$ and 45 days). The increasing rates of added biochar individually associated by a decrease of leachates content of $\mathrm{NO}_{3}-\mathrm{N}$ (meq/l) compared with control treatment. So, RC (\%) values of $\mathrm{NO}_{3}-\mathrm{N}$ in the leachates were negative at all individual application rates of biochar and became more negative with the increase rate of added biochar. The increased basic functional groups on Labiochars were beneficial to improve $\mathrm{NO}_{3}{ }^{-}$ and $\mathrm{PO}_{4}{ }^{3-}$ adsorption (Wang et al., 2015). On the other hand, the leachates of $\mathrm{NO}_{3}-\mathrm{N}$ (meq/L) from studied sandy soil increased with the increase rate of added compost alone compared with the control treatments (Table, 7). So, all RC (\%) of $\mathrm{NO}_{3}-\mathrm{N}$ contents in the leachates of samples treated with compost only were positive and increased with the increase of added compost. The trend effect of the individual applications 
either of biochar or compost on leachates $\mathrm{NO}_{3}-\mathrm{N}$ content was similar in the three leachings. Raw and composted animal manures provide physical, chemical and biological benefits but those can contribute to $\mathrm{NO}_{3}$ leaching in groundwater (Andraski et al., 2000).
Regarding the effect of amendments on the sandy soil content of leachate $\mathrm{NO}_{3}{ }^{-}$ (meq/L), Table (7) indicated that, there was an evident increase in soluble $\mathrm{NO}_{3}-(\mathrm{meq} / \mathrm{L})$ of leachate with increasing compost rates. While the increase in biochar rates led to very slight decrease in soluble $\mathrm{NO}_{3}-(\mathrm{meq} / \mathrm{L})$.

Table (7): Soluble $\mathrm{NO}_{3}-\mathrm{N}$ content (meq/L) in Leachate of and its relative change "RC" (\%) as affected by different applications of biochar (RSB) and/or compost (RSC) .

\begin{tabular}{|c|c|c|c|c|c|c|c|}
\hline \multirow{2}{*}{\multicolumn{2}{|c|}{ Organic amendments }} & \multicolumn{6}{|c|}{ Incubation periods } \\
\hline & & \multicolumn{2}{|c|}{$1^{\text {st }}$} & \multicolumn{2}{|c|}{$2^{\text {nd }}$} & \multicolumn{2}{|c|}{$3^{\text {th }}$} \\
\hline RSC $\%$ & RSB\% & $\begin{array}{c}\mathrm{NO}_{3} \\
\mathrm{meq} / \mathrm{L}\end{array}$ & RC\% & $\mathrm{meq} / \mathrm{l}$ & $\mathrm{RC} \%$ & $\begin{array}{c}\mathrm{NO}_{3} \\
\mathrm{meq} / \mathrm{L}\end{array}$ & $\mathrm{RC} \%$ \\
\hline \multirow{5}{*}{0.00} & 0.00 & 27.80 & 0.00 & 21.00 & 0.00 & 6.20 & 0.00 \\
\hline & 0.75 & 27.70 & -0.36 & 20.80 & -0.95 & 6.00 & -3.23 \\
\hline & 1.50 & 27.60 & -0.72 & 20.80 & -0.95 & 6.20 & 0.00 \\
\hline & 3.00 & 27.60 & -0.72 & 20.90 & -0.48 & 6.10 & -1.61 \\
\hline & Mean & 27.68 & -0.45 & 20.88 & -0.60 & 6.13 & -1.21 \\
\hline \multirow{4}{*}{0.75} & 0.00 & 28.00 & 0.72 & 22.30 & 6.19 & 6.00 & -3.23 \\
\hline & 0.75 & 27.90 & 0.36 & 21.70 & 3.33 & 6.00 & -3.23 \\
\hline & 1.50 & 27.90 & 0.36 & 22.10 & 5.24 & 5.90 & -4.84 \\
\hline & 3.00 & 27.70 & -0.36 & 22.00 & 4.76 & 5.80 & -6.45 \\
\hline & Mean & 27.88 & 0.27 & 22.03 & 4.88 & 5.93 & -4.44 \\
\hline \multirow{4}{*}{1.50} & 0.00 & 28.40 & 2.16 & 22.50 & 7.14 & 6.20 & 0.00 \\
\hline & 0.75 & 28.00 & 0.72 & 21.95 & 4.52 & 6.10 & -1.61 \\
\hline & 1.50 & 28.00 & 0.72 & 22.30 & 6.19 & 5.90 & -4.84 \\
\hline & 3.00 & 27.80 & 0.00 & 20.90 & -0.48 & 5.90 & -4.84 \\
\hline & Mean & 28.05 & 0.90 & 21.91 & 4.35 & 6.03 & -2.82 \\
\hline \multirow{5}{*}{3.00} & 0.00 & 29.10 & 4.68 & 23.00 & 9.52 & 6.30 & 1.61 \\
\hline & 0.75 & 28.90 & 3.96 & 21.98 & 4.67 & 6.30 & 1.61 \\
\hline & 1.50 & 28.70 & 3.24 & 22.20 & 5.71 & 6.99 & 12.74 \\
\hline & 3.00 & 28.70 & 3.24 & 22.24 & 5.91 & 6.80 & 9.68 \\
\hline & Mean & 28.85 & 3.78 & 22.36 & 6.45 & 6.60 & 6.41 \\
\hline
\end{tabular}


The relationship between application rates $(\mathrm{Ra})$ and the soluble content of $\mathrm{NO}_{3}$ (meq/L) in sandy soil leachate can be expressed with the following equation

Compost: $\mathrm{NO}_{3}{ }^{-}(\mathrm{meq} / \mathrm{L})=18.42+0.366 \mathrm{Ra}_{\mathrm{a}}$ $\left(R^{2}=0.971\right)$

Biochar: $\quad \mathrm{NO}_{3}{ }^{-}(\mathrm{meq} / \mathrm{L})=18.27-0.032 \mathrm{Ra}$ $\left(\mathrm{R}^{2}=0.303\right)$

Where, $R_{a}=$ The addition rates of amendment $\%$

The above equations revealed that in the case of compost, the increase in soluble $\mathrm{NO}_{3}{ }^{-}$(meq/L) in sandy soil leachate was $0.66 \mathrm{meq} / \mathrm{L}$ when compost was added by $1 \%$, while the decrease in case of biochar application was 0.032 per $1 \%$.

Concerning to the effect of the incubation periods on leachate content of soluble $\mathrm{NO}_{3}$ (meq/L), data in Table (7) indicated that, there was adecrease in $\mathrm{NO}_{3}{ }^{-}$(meq/L) of leachate with increasing incubation time. The relationships between studied incubation periods and the content of soluble $\mathrm{NO}_{3}{ }^{-}$(meq/L) produced from leaching sandy soil can be expressed with the following equations:

Compost: $\mathrm{NO}_{3}{ }^{-}(\mathrm{meq} / \mathrm{L})=57.7-1.107 \mathrm{P}$ $\left(\mathrm{R}^{2}=0.938\right)$

Biochar: $\quad \mathrm{NO}_{3}{ }^{-}(\mathrm{meq} / \mathrm{L})=55.9-1.078 \mathrm{P}$ $\left(R^{2}=0.957\right)$

Where, $\mathrm{P}=$ incubation periods (days)

These equations showed that, the decreasing rates in soluble $\mathrm{NO}_{3}{ }^{-}$content (meq/L) of leachate with increasing incubation time were the same in both cases of RSC and RSB.

\section{c. Soluble phosphorus (P) content}

Data in Table (8) represented the effect of compost and/or biochar on leachate content of soluble $P(\mathrm{mg} / \mathrm{L})$. The results illustrated that, the highest content of leachate $P$ was $43.30 \mathrm{mg} / \mathrm{L}$ at the $2^{\text {nd }}$ incubation period with treatment of $\mathrm{C}_{3} \mathrm{~B}_{0}$. The lowest content of leachate $P$ was 6.50 $\mathrm{mg} / \mathrm{L}$ at the $1^{\text {st }}$ incubation period with treatment of $\mathrm{C}_{0} \mathrm{~B}_{3}$.
- At $1^{\text {st }}$ incubation period: the highest leachate content of soluble $\mathrm{P}$ was 24.9 $\mathrm{mg} / \mathrm{L}$ with the treatment of $\mathrm{C}_{3} \mathrm{~B}_{0}$, while the lowest content was $6.50 \mathrm{mg} / \mathrm{L}$ with $\mathrm{C}_{0} \mathrm{~B}_{3}$.

- At the $2^{\text {nd }}$ incubation period: the highest leachate content of soluble $P$ was 43.30 $\mathrm{mg} / \mathrm{L}$ with the treatment of $\mathrm{C}_{3} \mathrm{~B}_{0}$, while the lowest content was $6.6 \mathrm{mg} / \mathrm{L}$ with $\mathrm{C}_{0} \mathrm{~B}_{3}$.

- At the $3^{\text {rd }}$ incubation period: the highest and the lowest leachate contents of soluble $P$ were 33.00 and $7.50 \mathrm{mg} / \mathrm{L}$ when compost and biochar were applied at $\mathrm{C}_{3} \mathrm{~B}_{0}$ and $\mathrm{C}_{0} \mathrm{~B}_{3}$ treatments, respectively.

The highest content of leachate $P$ can be obtained with $\mathrm{C}_{3} \mathrm{~B}_{0}$ treatment while, the lowest leachate $\mathrm{P}$ content obtained with $\mathrm{C}_{0} \mathrm{~B}_{3}$ treatment at the three incubation period.

With the combined applications of biochar and compost, soluble $\mathrm{P}$ content in leachate were lower than that resulted from the individual compost applications and were higher than the individual applications of biochar. So, RC (\%) values of the $\mathrm{P}$ content in the leachates of combined treatments in the first leaching were negative and higher than those associated with individual treatments of biochar. It is suggested that application of biochar can reduce the leaching of nutrients or even supplying nutrients to plants. Such trend was observed by Glaser et al. (2002), Lehmann et al. (2003) and Major et al., (2010). Also, Laird et al. (2010) reported that, the addition of biochar produced from hardwood to agricultural soil was significantly reduced total $\mathrm{N}$ and $\mathrm{P}$ leaching by $11 \%$ and $69 \%$, respectively.

Table (8) represnted the individual effect of compost and and biochar rates on soluble $P$ (meq/L) of studied samples leachate at three incubation periods $(25,35$ and 45 days). These data show that, the individual applications of biochar were associated by a decrease of leachates content of soluble $P$ compared with the control treatment in the 


\section{R. A. Khalil, et al.,}

three leachings. Similar trend was indicating by Novak et al. (2009) was found that, soil column experiment, biochar application significantly increased $P$ retention in soils and decreased $P$ levels in leachate solutions. So, RC (\%) for leachates values content of soluble $\mathrm{P}$ were negative with all individual applications of biochar in the three leachings.

Table (8): Soluble phosphorus content (mg/L) in Leachate of and its relative change "RC" (\%) as affected by different applications of biochar (RSB) and compost (RSC) at three incubation periods

\begin{tabular}{|c|c|c|c|c|c|c|c|}
\hline \multirow{2}{*}{\multicolumn{2}{|c|}{ Organic amendments }} & \multicolumn{6}{|c|}{ Incubation periods } \\
\hline & & \multicolumn{2}{|c|}{$1 \mathrm{st}$} & \multicolumn{2}{|c|}{$2^{\text {nd }}$} & \multicolumn{2}{|c|}{ 3th } \\
\hline $\mathrm{RSC} \%$ & RSB\% & $\mathrm{P} \mathrm{mg} / \mathrm{L}$ & $\mathrm{RC} \%$ & $\mathrm{mg} / \mathrm{L}$ & $\mathrm{RC} \%$ & $\mathrm{P} \mathrm{mg} / \mathrm{L}$ & $\mathrm{RC} \%$ \\
\hline \multirow{5}{*}{0.00} & 0.00 & 20.40 & 0.00 & 23.97 & 0.00 & 16.00 & 0.00 \\
\hline & 0.75 & 15.50 & -24.02 & 18.00 & -24.91 & 15.22 & -4.88 \\
\hline & 1.50 & 11.45 & -43.87 & 13.00 & -45.77 & 12.00 & -25.00 \\
\hline & 3.00 & 6.50 & -68.14 & 6.60 & -72.47 & 7.50 & -53.13 \\
\hline & Mean & 13.46 & -34.01 & 15.39 & -35.78 & 12.68 & -20.75 \\
\hline \multirow{5}{*}{0.75} & 0.00 & 22.13 & 8.48 & 33.50 & 39.76 & 27.00 & 68.75 \\
\hline & 0.75 & 18.00 & -11.76 & 25.88 & 7.97 & 19.50 & 21.88 \\
\hline & 1.50 & 15.50 & -24.02 & 21.00 & -12.39 & 16.99 & 6.19 \\
\hline & 3.00 & 12.33 & -39.56 & 16.50 & -31.16 & 13.00 & -18.75 \\
\hline & Mean & 16.99 & -16.72 & 24.22 & 1.04 & 19.12 & 19.52 \\
\hline \multirow{5}{*}{1.50} & 0.00 & 24.45 & 19.85 & 35.50 & 48.10 & 28.80 & 80.00 \\
\hline & 0.75 & 18.50 & -9.31 & 29.45 & 22.86 & 21.00 & 31.25 \\
\hline & 1.50 & 13.00 & -36.27 & 25.00 & 4.30 & 19.00 & 18.75 \\
\hline & 3.00 & 11.83 & -42.01 & 19.44 & -18.90 & 13.50 & -15.63 \\
\hline & Mean & 16.95 & -16.94 & 27.35 & 14.09 & 20.58 & 28.59 \\
\hline \multirow{5}{*}{3.00} & 0.00 & 24.90 & 22.06 & 43.30 & 80.64 & 33.00 & 106.25 \\
\hline & 0.75 & 17.90 & -12.25 & 32.82 & 36.92 & 29.00 & 81.25 \\
\hline & 1.50 & 13.00 & -36.27 & 29.00 & 20.98 & 24.50 & 53.13 \\
\hline & 3.00 & 11.50 & -43.63 & 27.00 & 12.64 & 18.83 & 17.69 \\
\hline & Mean & 16.83 & -17.52 & 33.03 & 37.80 & 26.33 & 64.58 \\
\hline
\end{tabular}


On the other hand, the individual applications of compost were associated with an increase the content $(\mathrm{mg} / \mathrm{L})$ of soluble $P$ in the studied leachates for the three leachings (Table, 8). So, RC (\%) values of leachates content of $\mathrm{P}$ were positive with all individual application of compost. In the same line Sims et al. (1998) reported an extensive review of $P$ loss in agricultural drainage when manure or fertilizer was applied to different soils and found significant leaching of $P$ following manure application. When $\mathrm{P}$ leaches through soil, it can eventually reach the ground water. In many cases, ground water emerges as surface water and thus can contribute to eutrophication if it contains sufficient P. In general, the addition of organic matter followed by incubation caused a decrease in the P-adsorption capacity of soil derived from basalt, thereby increasing the risk of $P$ pollution. These results were attributed to the changes of soil chemical properties followed by the applications of compost and other organic manures which resulting in an increase of $P$ availability and solubility. Similar discussion was out lined by Aiad, (2010), El-Gamal (2015) and Elgezery (2016).

Generally, leachate $P$ increased with increasing compost rates, while it decreased with increasing biochar rates at all studied incubation periods. The effect of compost or biochar rates on leachate $P$ can be expressed by the following equations:

Compost: $\mathrm{P}(\mathrm{mg} / \mathrm{L})=22.26+4.18 \mathrm{R}_{\mathrm{a}}\left(\mathrm{R}^{2}=0.90\right)$

Biochar: $P(\mathrm{mg} / \mathrm{L})=19.63-4.41 \mathrm{R}_{\mathrm{a}}\left(\mathrm{R}^{2}=0.90\right)$

Where, $\mathrm{P}=$ Soluble phosphorus $(\mathrm{mg} / \mathrm{L})$ in leachate

$\mathrm{R}_{\mathrm{a}}=$ Application rates (\%)

The previous equations revealed that, the relationship between compost rates and leachate $P$ was positive. The increasing rate of leachate $P$ was $4.18 \mathrm{mg} / \mathrm{L}$ for every $1 \%$ application rate of compost. On the other hand, the prior equation revealed that, the relationship between biochar application rates and obtained leachate $P$ was negative and decline rate of leachate $P$ was 4.41 $\mathrm{mg} / \mathrm{L}$ for the increasing in biochar as $1 \%$.

Regarding to the effect of incubation time (days) on leachate $P \mathrm{mg} / \mathrm{L}$ as affected by different rates of compost and/or biochar, data present in Table (8) revealed that, soluble $P$ was increased with increasing incubation period to 35 days and then it was decreased after 45 days. Data in Table (8) show a wide variation in leachates of the three leachings content $(\mathrm{mg} / \mathrm{L})$ of $P$ under different treatments of biochar and compost. The highest content $(\mathrm{mg} / \mathrm{l})$ of $P$ was found in the leachate of second leaching but the lowest one was found in the leachate of the first leaching. This trend may be related to the solubility degree of most $P$ compounds especially organic form presented in the soil and the added organic substances. The relationship between incubation time and leachate $P \mathrm{mg} / \mathrm{L}$ can be expressed by the following equations:

Compost: $P(\mathrm{mg} / \mathrm{L})=-0.095 \mathrm{P}^{2}+6.799 \mathrm{P}_{\mathrm{i}}-$ $87.75 \quad(R 2=0.999)$

Biochar: $\quad P(\mathrm{mg} / \mathrm{L})=-0.023 \mathrm{Pi}^{2}+$ $1.586 \mathrm{P}_{\mathrm{i}}-11.67 \quad(\mathrm{R} 2=0.999)$

$\mathrm{P}_{\mathrm{i}}=$ incubation time (days)

These equations can be used to predict the values of leaching $P$ after limited time.

\section{d. Soluble potassium (K) content}

The content of soluble $\mathrm{K}(\mathrm{mg} / \mathrm{L})$ in the leachates of sandy soil treated by RSC and RSB individually and together and its relative changes "RC" (\%) were recorded in Table (9). These data showed that, all individual and combined treatments of RSC and RSB were associated by an increase of leachates content of soluble $\mathrm{K}$. These increases were found in the three leachings. The highest value was $7063 \mathrm{mg} / \mathrm{L}$ at the first leaching with $\mathrm{C}_{3} \mathrm{~B}_{3}$ treatment, while the lowest content of soluble $\mathrm{K}$ was $69.7 \mathrm{mg} / \mathrm{L}$ with $\mathrm{C}_{0} \mathrm{~B}_{0}$ treatment at the third leaching. The highest and lowest values of soluble $\mathrm{K}$ in the leachate at the first incubation period were 7063.4 and $224.7 \mathrm{mg} / \mathrm{L}$ with $\mathrm{C}_{3} \mathrm{~B}_{3}$ and $\mathrm{C}_{0} \mathrm{~B}_{0}$ 


\section{R. A. Khalil, et al.,}

treatments, respectively. At the second incubation period, the highest and the lowest values of leachate $\mathrm{K}$ were 2439.3 and 144.0 $\mathrm{mg} / \mathrm{L}$ with $\mathrm{C}_{3} \mathrm{~B}_{3}$ and $\mathrm{C}_{0} \mathrm{~B}_{0}$ treatments, respectively. At the third incubation period, the highest and lowest content of soluble $\mathrm{K}$ were 1401.4 and $69.7 \mathrm{mg} / \mathrm{L}$ with treatment of $\mathrm{C}_{3} \mathrm{~B}_{3}$ and $\mathrm{C}_{0} \mathrm{~B}_{0}$, respectively. These results pointed out that, the values of soluble leachate $\mathrm{K}$ increased with increasing compost and/ or biochar rates.

Table (9): Soluble potassium content ( $\mathrm{mg} / \mathrm{L}$ ) in Leachate of and its relative change "RC" (\%) as affected by different applications of biochar (RSB) and compost (RSC) at three incubation periods

\begin{tabular}{|c|c|c|c|c|c|c|c|}
\hline \multirow{2}{*}{\multicolumn{2}{|c|}{ Organic amendments }} & \multicolumn{6}{|c|}{ incubation periods } \\
\hline & & \multicolumn{2}{|c|}{$1^{\text {st }}$} & \multicolumn{2}{|c|}{$2^{\text {nd }}$} & \multicolumn{2}{|c|}{$3^{\text {th }}$} \\
\hline RSC\% & RSB $\%$ & $\mathrm{~K} \mathrm{mg/L}$ & $\mathrm{RC} \%$ & $\mathrm{mg} / \mathrm{L}$ & $\mathrm{RC} \%$ & $\mathrm{~K} \mathrm{mg/L}$ & $\mathrm{RC} \%$ \\
\hline \multirow{5}{*}{0.00} & 0.00 & 224.70 & 0.00 & 144.00 & 0.00 & 69.66 & 0.00 \\
\hline & 0.75 & 680.10 & 202.67 & 464.80 & 222.78 & 200.63 & 188.01 \\
\hline & 1.50 & 2262.40 & 906.85 & 627.80 & 335.97 & 320.46 & 360.03 \\
\hline & 3.00 & 5734.50 & 2452.07 & 1198.30 & 732.15 & 507.77 & 628.92 \\
\hline & Mean & 2225.43 & 890.40 & 608.73 & 322.73 & 274.63 & 294.24 \\
\hline \multirow{5}{*}{0.75} & 0.00 & 623.60 & 177.53 & 221.60 & 53.89 & 110.66 & 58.86 \\
\hline & 0.75 & 926.80 & 312.46 & 728.60 & 405.97 & 288.31 & 313.88 \\
\hline & 1.50 & 1843.30 & 720.34 & 1263.70 & 777.57 & 492.02 & 606.32 \\
\hline & 3.00 & 5841.40 & 2499.64 & 1423.00 & 888.19 & 724.57 & 940.15 \\
\hline & Mean & 2308.78 & 927.49 & 909.23 & 531.41 & 403.89 & 479.80 \\
\hline \multirow{5}{*}{1.50} & 0.00 & 1003.50 & 346.60 & 524.20 & 264.03 & 245.90 & 253.00 \\
\hline & 0.75 & 1648.30 & 633.56 & 939.70 & 552.57 & 396.86 & 469.71 \\
\hline & 1.50 & 2436.90 & 984.51 & 1375.30 & 855.07 & 577.26 & 728.68 \\
\hline & 3.00 & 5460.00 & 2329.91 & 2104.50 & 1361.46 & 990.91 & 1322.50 \\
\hline & Mean & 2637.18 & 1073.64 & 1235.93 & 758.28 & 552.73 & 693.47 \\
\hline \multirow{5}{*}{3.00} & 0.00 & 2016.20 & 797.29 & 1073.70 & 645.63 & 422.41 & 506.38 \\
\hline & 0.75 & 2881.50 & 1182.38 & 1563.00 & 985.42 & 622.35 & 793.41 \\
\hline & 1.50 & 3810.10 & 1595.64 & 1947.70 & 1252.57 & 782.37 & 1023.12 \\
\hline & 3.00 & 7063.40 & 3043.48 & 2439.30 & 1593.96 & 1401.35 & 1911.70 \\
\hline & Mean & 3942.80 & 1654.70 & 1755.93 & 1119.39 & 807.12 & 1058.65 \\
\hline
\end{tabular}


At the same individual application rate of either biochar or compost, the treatments of biochar were associated by high increases of leachates content of soluble $\mathrm{K}$ compared with the individual treatments of compost. More increases of soluble $\mathrm{K}$ were found in the leachates with the combined treatments of biochar and compost. Similar observation was obtained by Kamara et al. (2015) who found that, rice straw biochar was rich in exchangeable cations especially K (39.7 $\mathrm{cmol} / \mathrm{kg}$ biochar) as compared to $\mathrm{Mg}$ (5.8 $\mathrm{cmol} / \mathrm{kg}$ biochar) and $\mathrm{Ca}(12.6 \mathrm{cmol} / \mathrm{kg}$ biochar). In addition, Widowati et al. (2014) concluded that, potassium in biochar can be dissolved and leached. Also, Lehmann et al. (2003) found that $K$ in the leachate increased after the addition of biochar to soil, giving high $\mathrm{K}$ content of biochar to soil. El-Gamal (2015) and Elgezery (2016) concluded that, there are increases in calcareous and sandy soils content of available $\mathrm{K}$ followed by an increase of application rates of soil organic amendments ( biogas manure and compost). Table (9) represented the individual effect of amendments rates (compost or biochar) and incubation periods on $\mathrm{K}$ leachate. The following equations can be used to express the effect of amendments rates (compost or biochar):

compost: $\mathrm{K}(\mathrm{mg} / \mathrm{L})=99.2+348.6 \mathrm{Ra}\left(\mathrm{R}^{2}=0.91\right)$ biochar: $\mathrm{K}(\mathrm{mg} / \mathrm{L})=14.9+800.9 \mathrm{Ra}_{\mathrm{a}}\left(\mathrm{R}^{2}=0.98\right)$

Where, $\mathrm{K}$ is soluble phosphorus $(\mathrm{mg} / \mathrm{L})$ in leachate and $\mathrm{Ra}$ is application rates (\%) of compost or biochar

These equations indicated that, the soluble $\mathrm{K}$ rate in the case of biochar was higher than compost by 2.3 times. In the case of biochar the soluble $\mathrm{K}$ was 800.9 $\mathrm{mg} / \mathrm{L}$ per addition $1 \%$ biochar, where in the case of compost the soluble $\mathrm{K}$ in the leachate was $348.6 \mathrm{mg} / \mathrm{L}$ with $1 \%$ compost.

It can expressed the effect of incubation periods (days) on the soluble rates of $K$ in sandy soil leachate by the following equation:
Compost: $\mathrm{K}=1877.7-37.7 \mathrm{P} \quad\left(\mathrm{R}^{2}=0.98\right)$

Biochar: $K=4450.2-97.5 P \quad\left(R^{2}=0.95\right)$

Where $\mathrm{P}=$ Incubation period (days).

These equations revealed that, the rate of soluble $\mathrm{K}$ per day in the case of biochar was higher than the compost by 2.4 times.

\section{REFERENCES}

Abou Hussien, E. A., M. N.E. Faiyad, W. M. A. Nada and M. Kh. Elgezery (2017). Effect of sulphur additives on the chemical composition of compost. Menoufia J. Soil Sci., (2): 59-72

Agegnehu, G., A. M. Bass, P. N. Nelson and M. I. Bird (2016). Benefits of biochar, compost and biochar-compost for soil quality, maize yield and greenhouse gas emissions in a tropical agricultural soil. Science of the Total Environment, 543 :295-306.

Aiad, N. A. (2010). Application of organic wastes for sustainable of agriculture.Ph. D. Thesis, Fac. of Agric., Menoufia Univ., Egypt.

Ali, Laila. K. M. (2001). Use of improved organic fertilizers as nutrients sources. Ph.D Thesis .Soil Sci Dept . Fac of Agric. Ain Shams Univ.

Andraski, T. W., L. G. Bundy and K. R. Brye (2000). Crop management and corn nitrogen rate effects on nitrate leaching. Journal of Environmental Quality, 29(4): 1095-1103.

Angelova, V. R., V. I. Akova, N. S. Artinova and K. I. Ivanov (2013). The effect of organic amendments on soil chemical characteristics. Bulg. J. Agric. Sci, 19(5) :958-971.

Arthur, E., W. Cornelis and F. Razzaghi (2012). Compost amendment to sandy soil affects soil properties and greenhouse tomato productivity. Compost Science and Utilization, 20(4): 215-221.

Cottenie, A., M. Verloo, L. Kickens, G. Velghe and R. Camerlynck (1982). Chemical analysis of plants and soils. 
Laboratory of Analytical and Agrochemistry. State University, Ghent Belgium, pp: 63.

Ding, Y., Y. X. Liu, W. X. Wu, D. Z. Shi, M. Yang and Z. K. Zhong (2010). Evaluation of biochar effects on nitrogen retention and leaching in multi-layered soil columns. Water, Airand Soil Pollution, 213(1-4): 47-55.

El-Gamal, B. A. H. (2015). Effect of some soil amendments on soil conditions and plant growth. Ph. D. Thesis, Fac. of Agric., Menoufia Univ., Egypt.

Elgezery, M. Kh. (2016). Effect of organic additves on effeicency of sulphur fertilization. M.Sc. Thesis, Fac. of Agric., Menoufia Univ., Egypt.

Epstein, E. (1997). The Science of Composting, Technomic Pub. Co., Lancaster, PA, 487.

Fischer, D. and B. Glaser (2012). Synergisms between compost and biochar for sustainable soil amelioration. In Management of Organic Waste. InTech.

Fowles, M. (2007). Black carbon sequestration as an alternative to bioenergy. Biomass and Bioenergy, 31(6): 426-432.

Gaskin, J. W., C. Steiner, K. Harris, K. C. Das and B. Bibens (2008). Effect of lowtemperature pyrolysis conditions on biochar for agricultural use. Transactions of the ASABE, 51(6): 2061-2069.

Glaser, B., J. Lehmann and W. Zech (2002). Ameliorating physical and chemical properties of highly weathered soils in the tropics with charcoal-a review. Biology and Fertility of Soils, 35(4): 219-230.

Gohar, H. M. (2011). Effect of some plant residues on soil properties and plant growth in newly reclaimed soils. M. Sc. Thesis, Fac. of Agric.,Menoufia Univ., Egypt.

Goulding, K. (2000). Nitrate leaching from arable and horticultural land. Soil Use and Management, 16(s1): 145-151.
Granatstein, D., C. Kruger, H. Collins, M. Garcia-Perez and J. Yoder (2009). Use of biochar from the pyrolysis of waste organic material as a soil amendment. Center for Sustaining Agric. Nat. Res. Washington State University, Wenatchee, WA. WSDA Interagency Agreement. C, 800248.

Hewitt, E.J. and T.A. Smith (1975). plant mineral, unibook, english universities press Ltd. printed in great Britain by Elelcher of Son Ltd Norwich.

Iqbal, H., M. Garcia-Perez and M. Flury (2015). Effect of biochar on leaching of organic carbon, nitrogen, and phosphorus from compost in bioretention systems. Science of the Total Environment, 521: 37-45.

Kamara, A., H. S. Kamara and M. S. Kamara (2015). Effect of rice straw biochar on soil quality and the early growth and biomass yield of two rice varieties. Agricultural Sciences, 6(08): 798.

Klute, A. and C. Dirksen (1986). Hydraulic conductivity and diffusivity. In Klute, A. (Ed.) Methods of soil analysis. Part (I) Physical and mineralogical methods, 2nd ed. Agron, Monogr. 9. ASA-SSA, Madison, WI, PP. 687- 734.

Kookana, R. S., A. K. Sarmah, L. Van Zwieten, E. Krull and B. Singh (2011). biochar application to soil: agronomic and environmental benefits and unintended consequences. Advancesin Agronomy, (112): 103-143.

Krull, E. S., J. A. Baldock, J. O. Skjemstad and R. J. Smernik (2009). Characteristics of biochar: organo-chemical properties. Biochar for environmental management: Science and Technology, 53.

Kumar, G. V., G. Renuka and Y. Anoop (2008). Potential of vermicomposting technology in solid waste management. In Current developments in solid-state fermentation (pp. 468-511). Springer New York. 
Laird, D., P. Fleming, B. Wang, R. Horton and D. Karlen (2010). Biochar impact on nutrient leaching from a Midwestern agricultural soil. Geoderma, 158(3): 436442.

Lehmann, J. (2007a). Bio-energy in the black. Frontiers in Ecology and the Environment, 5(7): 381-387.

Lehmann, J. and S. Joseph (2009). Biochar for Environmental Management: Science and Technology; Earthscan: London and Sterling, VA.

Lehmann, J., J. P. da Silva, C. Steiner, T. Nehls, W. Zech and B. Glaser (2003). Nutrient availability and leaching in an archaeological Anthrosol and a Ferralsol of the Central Amazon basin: fertilizer, manure and charcoal amendments. Plant and Soil, 249(2): 343-357.

Major, J., M. Rondon, D. Molina, S. J. Riha and J. Lehmann (2010). Maize yield and nutrition during 4 years after biochar application to a Colombian savanna oxisol. Plant and Soil, 333(1-2): 117-128.

Marofi, S., M. Shakarami, G. Rahimi and F. Ershadfath (2015). Effect of wastewater and compost on leaching nutrients of soil column under basil cultivation. Agricultural Water Management, 158: 266-276.

Nigussie, A., E. Kissi, M. Misganaw and G. Ambaw (2012). Effect of biochar application on soil properties and nutrient uptake of lettuces (Lactuca sativa) grown in chromium polluted soils. AmericanEurasian Journal of Agricultural and Environmental Sciences, 12(3): 369-376.

Novak, J., D. W. Watts, K. Cantrell, K. A. Spokas, K.S. Ro and B. Glaz (2012). Biochars impact on phosphorus and potassium release into soil and water leachates. Visions for Asustainable Planet: ASA, CSSA, and SSSA International Annual Meetings Cincinnati, Ohio.

Novak, J. M., W. J. Busscher, D. L. Laird, M. Ahmedna, D. W. Watts and M. A. Niandou (2009). Impact of biochar amendment on fertility of a southeastern coastal plain soil. Soil Science, 174(2): 105-112.

Page, A. L., R. H. Miller and D. R. Keeney (1982). Methods of Soil Analysis,Part 2. Chemical and Microbiological properties second Edition. Wisconsin, U.S.A.

Peverly, J. H. and P. B. Gates (1994). Nitrogen mineralization studies in corn and vineyard plots treated with composts of differing $\mathrm{C} / \mathrm{N}$ ratio. In National Conference on Solid Waste Composting Council.

Sims, J.T., R.R. Simard and B.C. Joern (1998). Phosphorus loss in agricultural drainage: historical perspective and current research. J. Environ. Qual., 27: 277-293.

Speir, T. W., J. Horswell, A. P. Van Schaik, R. G. McLaren and G. Fietje (2004). Composted biosolids enhance fertility of a sandy loam soil under dairy pasture. Biology and Fertility of Soils, 40(5): 349-358.

Wang, Z., H. Guo, F. Shen, G. Yang, Y. Zhang, Y. Zeng and S. Deng (2015). Biochar produced from oak sawdust by lanthanum (La)-involved pyrolysis for adsorption of ammonium $\left(\mathrm{NH}_{4}^{+}\right)$, nitrate (NO3 ${ }^{-}$), and phosphate $\left(\mathrm{PO}^{3-}{ }^{-}\right.$. Chemosphere, 119: 646-653.

Widowati, W., A. Asnah and W. H. Utomo (2014). The use of biochar to reduce nitrogen and potassium leaching from soil cultivated with maize. Journal of Degraded and Mining Lands Management, 2(1): 211-218.

Xu, G., J. Sun, H. Shao and S. X. Chang (2014). Biochar had effects on phosphorus sorption and desorption in three soils with differing acidity. Ecological engineering, 62: 5460.

Zhao, X., X. Yan, Y. Xie, S. Wang, G. Xing and Z. Zhu (2016). Use of Nitrogen Isotope to Determine Fertilizer-and SoilDerived Ammonia Volatilization in a Rice/Wheat Rotation System. Journal of Agricultural and Food Chemistry, 64(15): 3017-3024. 


\section{تأثير إضافات البيوتثار والكمبوست على فقد المغذيات الكبرى من الأرض الرملية}

رفعت أحمد خليل ، محمد أبوالفضل أحمد، صلاح عبدالمجيد رضوان ،

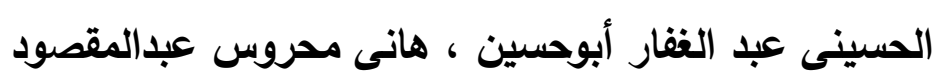

قسم علوم الأراضى - كلية الزراعة - جامعه المنوفية - مصر

الملخص العربى

أجريت تجربة كولم فى معمل قسم علوم الأراضى كلية الزراعة جامعة الدنوفية بشبين الكوم لدراسة تأثير إضافة نوعين

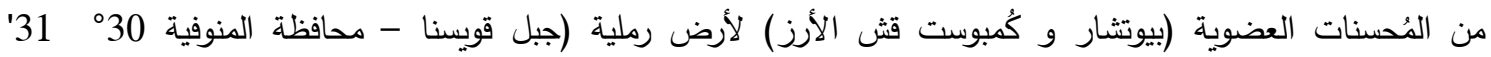

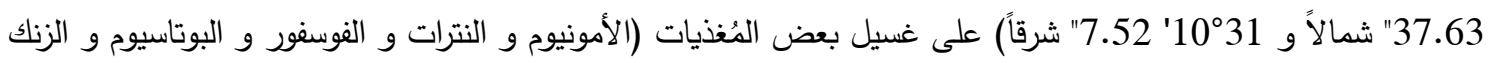
و النحاس). أجريت هذه الدراسة باستخدام اعمدة من البولى إيثلين بقطر

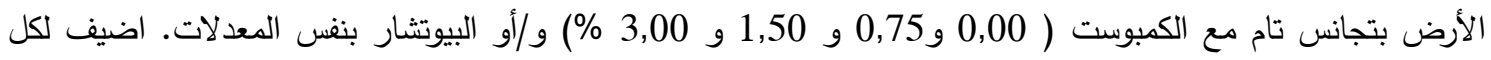
الاعمدة محلول مغذى (Hewitt and Smith, 1975) وحضنت لمدة 25 يوم تحت مستوى رطوبة السعة الحقلية ودرجة حرارة الغرفة. فى نهاية فترة التحضين كل الأعمدة أضيف لها ماء يعادل 180 \% من من السعة المائية لـعاملة الكنترول (بدون معاملات) لثلاث مرات بفاصل زمنى 10 أيام. تم تجميع الراشح من كل كولم على حده وحلل لمعرفة محتواه من رقم

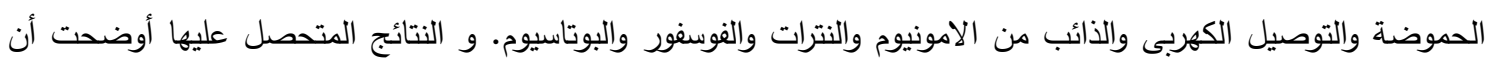
إضافة البيوتشار أدت إلى زيادة التوصيل الكهربى ورقم الحموضة ومحتوى البوتاسيوم الذائب فى الراشح ونقص فئس في الأمونيوم

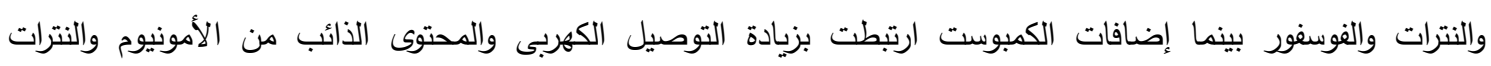
والفوسفور والبوتاسيوم فى الراشح ونقص فى رقم الحموضة. 